\title{
Prevalence of Histological Characteristics of Breast Cancer in Rwanda in Relation to Age and Tumor Stages
}

\author{
Jeanne P. Uyisenga ${ }^{1,2} \cdot$ Yvan Butera $^{3,4} \cdot$ Ahmed Debit $^{2} \cdot$ Claire Josse $^{2,4,5} \cdot$ Costas C. Ainhoa $^{3} \cdot$ Emile Karinganire $^{3} \cdot$ \\ Aimee P. Cyuzuzo ${ }^{1}$ • Nicole Umurungi ${ }^{1}$ • Yves Kalinijabo ${ }^{1}$ - Simeon Uwimana ${ }^{6}$ - Leon Mutesa ${ }^{7}$ (D) Vincent Bours $^{2,8}$
}

Received: 6 April 2020 / Accepted: 14 July 2020 / Published online: 9 August 2020

(C) Springer Science+Business Media, LLC, part of Springer Nature 2020

\begin{abstract}
Breast cancer is a complex disease, and it is the most common cause of morbidity and mortality among women worldwide. In Sub-Saharan Africa, the clinical characteristics and tumor profiles of breast cancer are still unknown. In the present study we aimed to determine breast tumor profiles of the Rwandan patients in relation to age and tumor stages. We compare our findings to related results from other sub-Saharan Africa studies. Data on age at diagnosis, tumor stage, and hormonal profiles of 138 patients diagnosed between January 2015 and December 2018 were retrospectively retrieved from electronic medical records at three referral hospitals in Rwanda. We compared our results to related findings reported in other Sub-Saharan African countries. All statistical analyses were done using SPSS Inc., Chicago, IL, USA, version 20 and R software languages. The mean age at diagnosis was 49.7 years $(\mathrm{SD}=13)$ and ranged from 17 to 86 years. The majority of patients $(57.2 \%)$ were diagnosed before 50 years of age compared with $42.8 \%$ aged $>50$ years. Tumor stage III was the commonest accounting for $62 \%$ followed by stage II with 24.8\%. The distribution of breast tumor subtypes was ER-, PR-, HER2-: 37.7\%; ER+, PR+, HER2-: 31.2\%; ER-, PR-, HER2+: $14.5 \%$; ER+, PR+, HER2+: $5.1 \%$; and other subtypes represented $11.6 \%$. There was no statistically significant difference in age and tumor stages between the molecular subtypes. Our findings revealed the predominance of hormonal negative tumors among Rwandan patients with breast cancer. Triple negative was found to be the most common breast tumor subtype regardless of age and tumor stage. Larger prospective studies could examine genetics and environmental factors that may play a role in the differences of tumor characteristics in Sub-Saharan populations.
\end{abstract}

Keywords Breast cancer $\cdot$ Molecular subtypes $\cdot$ Rwanda $\cdot$ Sub-Saharan Africa

Vincent Bours

vbours@uliege.be

1 College of Science and Technology, University of Rwanda, 4285 Kigali, Rwanda

2 Laboratory of Human Genetics, GIGA Research Institute, University of Liege, B34, +2, 4000 Liege, Belgium

3 Rwanda Cancer Centre, Rwanda Military Hospital, Kanombe, 4062 Kigali, Rwanda

4 Department of Medical Oncology, University Hospital (CHU Liege), B35, 2, 4000 Liege, Belgium

5 Laboratory of Medical Oncology, GIGA Research Institute, University of Liege, B34, +2, 4000 Liege, Belgium

6 Kigali University Teaching Hospital, PO Box 655, Kigali, Rwanda

7 Center for Human Genetics, College of Medicine and Health Sciences, University of Rwanda, 4285 Kigali, Rwanda

8 Department of Human Genetics, University of Liege, CHU Liege, Liege, Belgium

\section{Background}

Breast cancer (BC) is the most commonly diagnosed and deadly malignancy in women in both developed and developing countries with about 2.1 million cases and 627,000 deaths registered in 2018 [1]. It causes $25.1 \%$ of all cancer deaths each year in developed countries and is the leading cause of mortality among women in developing countries with $14.3 \%$ of all deaths annually. The GLOBOCAN estimates that the $\mathrm{BC}$ incidence will double by the year 2050 [2].

In Sub-Saharan Africa (SSA), BC is becoming a serious public health issue with a significant increase in its incidence, and a high mortality rate as compared with developed parts of the world [3, 4]. In Rwanda, a small country of $26,338 \mathrm{~km}^{2}$ and more than 12 million inhabitants, $\mathrm{BC}$ is currently the most commonly diagnosed cancer in women and the second cause of mortality after cervical cancer $[5,6]$. It has been suggested that specific biological characteristics might explain the adverse prognosis of $\mathrm{BC}$ in Africa [7, 8]. 
$\mathrm{BC}$ is a heterogeneous disease with different morphological and molecular subtypes $[9,10]$. The treatment and routine clinical management of BC rely on hormonal receptor (HR) status such as the presence or absence of estrogen receptor (ER), progesterone receptor (PR), and human epidermal growth factor 2 (HER2) combined with other prognostic factors such us patient age, tumor histology, tumor stage, and nodal status [11, 12]. A combination of ER, PR, and HER2 defines distinct tumor classes of $\mathrm{BC}$ that are further defined by gene expression profiles. The knowledge of tumor subtype may enable more accurate diagnoses and support therapeutic decisions. In clinical settings, tumor subtypes are classified using immunohistochemistry (IHC) markers and guide prognosis and targeted therapies for ER/PR or HER2 positive tumors. ER/PR positive tumors are candidate for hormonal (endocrine) therapy, whereas HER2 positive tumors are targeted with anti-HER2 therapies. Triple negative (ERnegative, PR negative, HER2 negative) tumors lack any target therapy [13].

Little is known about the rate and features of BC in Africa. The few studies conducted in SSA on clinico-pathological and biological characteristics of $\mathrm{BC}$ report that it is characterized by an early age of onset and an advanced stage at diagnosis with poor prognosis. However, the reports concerning hormone receptor and molecular subtypes are contradictory. A review by Brinton et al. [14] found that most breast tumors in African women are hormone receptor negative, while others reported the predominance of hormone receptor positive breast tumors.

In the present study, we aimed at providing information on the clinical presentation and hormonal receptor profiles of breast cancer in Rwanda through a large collection of cases from three major hospitals. We also compared our results with reports from previous studies in other SSA countries.

\section{Material and Methods}

\section{Study Design and Setting}

This is a descriptive retrospective study conducted at three referral hospitals in Rwanda: University Teaching Hospital of Butare (CHUB) located in the Southern province, University Teaching Hospital of Kigali (CHUK), and Rwanda Military Hospital (RMH) at Kanombe, both located in Kigali, capital city of Rwanda. BC patients are referred from all over the country to these three referral hospitals.

\section{Data Collection}

Data including hormonal profile (ER, PR) and HER2 expression, demographic information (gender, age at diagnosis), and tumor characteristics (tumor stage or grade) were collected through review of patients electronic medical records from
January 2015 to December 2018. Immunohistochemistry (IHC) staining for ER, PR, and HER2 was performed at one referral hospital. The biopsy or surgical specimens received from all three hospitals were originally fixed in $10 \%$ formalin. They were then fixed in $10 \%$ neutral buffered formalin for 24 to $72 \mathrm{~h}$ and then processed for routine hematoxylin and eosin staining through the steps of dehydration, clearing, paraffin impregnation, and finally sectioning and staining. Hormonal receptor and HER2 statuses were identified by immunohistochemical (IHC) markers using EnVision ${ }^{\mathrm{TM}}$ Flex Kit (Dako, Denmark)-Manual protocol, and following the manufacturer instructions. For each run of staining, a positive and negative control slide was also prepared. The positive control slides were prepared from breast carcinoma known to be positive for the antigen under study. The negative control slides were prepared from the same tissue block but incubated with PBS instead of the primary antibody. A semi-quantitative histochemical score was used to record results of ER and PR staining according to the system established by Allred et al. [15]. This system considers both the pro-portion and intensity of stained cells. The intensity score (IS) ranges from 0 to 3 , with 0 being no staining, 1 weak staining, 2 moderate staining, and 3 strong staining. The proportion score (PS) estimates the proportion of positive tumor cells and ranges from 0 to 5 , with 0 being non-reacting, 1 for $1 \%$ reacting tumor cells, 2 for $10 \%$, 3 for one-third, 4 for two-thirds, and 5 if $100 \%$ of tumor cells show reactivity. The PS and IS are added to obtain a total score (TS) that ranges from 0 to 8 . Tumor cells with a total score of 3 to 8 were considered positive, whereas those with TS less than 3 were considered negative cases.

Her-2/neu was scored on a 0 to 3 scale according to the criteria for Intensity and Pattern of Cell Membrane Staining with pathway HER2. The staining was scored as negative (0) when no membrane staining was observed, or (1+) when membranous staining was faint, partial staining of the membrane in any proportion of the cancer cells; weakly positive $(2+)$ if weak complete staining of the membrane, greater than $10 \%$ of cancer cells; and positive (3+) if intense complete staining of the membrane, greater than $10 \%$ of cancer cells. The procedure was standardized in comparison with the Hercep Test (DAKO) kit. Tumor grades were classified using the Nottingham Bloom-Richardson grading system [16], and clinical tumor stages were classified according to American Joint Committee on Cancer and TNM classification [17]. All histological evaluations and pathological reporting were in compliance with the American Society of Clinical Oncology/College of American Pathologists (ASCO/CAP) Guidelines as updated (www.cap.org).

We also reviewed published studies from SSA countries paying attention to data concerning the mean/median age, the proportions of patients aged of 50 years or less, the percentage of stage III\&IV tumors, the percentage of triple negative tumors, and the percentage of HER2-enriched tumors. 


\section{Data Analysis}

Data were organized into a secure, electronic database and checked for duplications and errors by independent people. We used descriptive statistics to report the mean and standard deviation (SD) for continuous data and frequencies and proportions for categorical data. Chi-square or ANOVA test was used to evaluate the statistical significance of the association between hormonal/ tumor subtypes with patient's age and tumor stage. We classified hormonal statuses into five tumor subtypes: ER+, PR+, HER2+ (triple positive), ER-, PR-, HER2- (triple negative), ER+, PR+, HER2-, ER-, PR-, HER2+ (HER2-enriched), and others (ER-, PR+, HER2+; ER-, PR+, HER2-; ER+, PR-, HER2-). To test for age, two groups were considered: young (patients aged 50 years and under) and old (patients above 50 years). The tumor stages were divided into three categories: early stage (stages I and II), locally advanced (stage III), and metastatic (IV).

Results from studies in SSA on proportions of young patients, advanced tumor stage, triple negative tumors, and HER2-enriched were summarized in the table. Proportions of triple negative tumors from those studies were grouped according to geographical location in Africa and metaanalyzed using an inverse variance method. The proportion estimates were calculated under the random effect model. Confidence intervals for proportions were calculated using the exact binomial method.

The significance level was fixed at 5\%. Data analysis was performed using SPSS Inc., Chicago, IL, USA, version 20, and meta-proportions were plotted using $\mathrm{R}$ software language.

\section{Ethical Consideration}

Ethical approval was obtained from the Institutional Review Board of the College of Medicine and Health Sciences (CMHS) at University of Rwanda (Reference No 209/ CMHS IRB/2017).

\section{Results}

\section{Clinical Pathology Characteristics of Study Participants}

A total number of 138 breast cancer cases with available data for all variables considered in the present study were recorded. Of all cases, $98 \%$ was female while only $2 \%$ was male. The mean age at diagnosis was 49.7 years $(\mathrm{SD}=13)$ and ranged from 17 to 86 years. The majority of patients $(57.2 \%)$ were diagnosed before the age of 50 years compared with $42.8 \%$ aged $>50$ years. Among these, $9.4 \%$ was younger than 35 years old. Bilateral breast cancer was recorded in 2 $(1.4 \%)$ patients.
Histologically, invasive ductal carcinoma accounted for the majority of the patients with $81.9 \%$ of cases, followed distantly by invasive lobular carcinoma with $8.7 \%$.

The tumor stage III was the commonest accounting for $62.5 \%(80 / 128)$ followed by stage II with $24.8 \%$. Stage I and stage IV represented $7.0 \%$ and $7.8 \%$ of all cases, respectively.

Lymph node invasion was observed in the majority of patients $70.6 \%$ (77/109) compared with $29.4 \%$ (32/109) node negative tumors (Table 1 ).

\section{Hormonal Receptor Profiles in Relation with Age and Tumor Stage at Presentation}

In general, hormonal receptor negative tumors were predominant compared with hormonal receptor positive: $55.1 \%$ ER-

Table 1 Clinical pathology characteristics of study participants

\begin{tabular}{|c|c|c|}
\hline Variables & Frequency $(n=138)$ & Percentage \\
\hline \multirow{2}{*}{\multicolumn{3}{|c|}{$\begin{array}{l}\text { Age: mean } \pm \text { SD: } 49.7 \pm 12.98 \\
\text { Range } 17-86\end{array}$}} \\
\hline & & \\
\hline$<35$ & 13 & 9.4 \\
\hline $35-50$ & 66 & 47.8 \\
\hline$>50$ & 59 & 42.8 \\
\hline \multicolumn{3}{|l|}{ Gender } \\
\hline $\mathrm{F}$ & 135 & 97.8 \\
\hline M & 3 & 2.2 \\
\hline \multicolumn{3}{|l|}{ Breast laterality } \\
\hline Left & 72 & 52.2 \\
\hline Right & 45 & 32.6 \\
\hline Bilateral & 2 & 1.4 \\
\hline Missing & 19 & 13.8 \\
\hline \multicolumn{3}{|l|}{ Histology } \\
\hline Ductal carcinoma in situ & 2 & 1.4 \\
\hline Invasive ductal carcinoma & 113 & 81.9 \\
\hline Invasive lobular carcinoma & 12 & 8.7 \\
\hline Medullary & 5 & 3.6 \\
\hline Metaplastic & 3 & 2.2 \\
\hline Sarcoma of the breast & 1 & 0.7 \\
\hline Colloid carcinoma & 1 & 0.7 \\
\hline \multicolumn{3}{|l|}{ Tumor stage } \\
\hline I & 9 & 6.5 \\
\hline II & 38 & 27.5 \\
\hline III & 73 & 52.9 \\
\hline IV & 10 & 7.2 \\
\hline Missing & 8 & 5.8 \\
\hline \multicolumn{3}{|l|}{ Lymph node involvement } \\
\hline Yes & 77 & 55.8 \\
\hline No & 32 & 23.2 \\
\hline Missing & 28 & 20.3 \\
\hline
\end{tabular}


vs. $44.9 \% \mathrm{ER}+, 63.8 \% \mathrm{PR}-$ vs. 36.2 PR+, and 78.3\% HER2vs. 21.7 HER2+. Hormonal receptor negative tumors were most common in the younger age group $(\leq 50$ years) and at advanced tumor stages. However, the association between age and hormonal status was not statistically significant $(p>0.05)$. We observed a statistically significant association between tumor stage and ER status $(p=0.00097)$. However, the association between PR, HER2, and tumor stages was not statistically significant $(p>0.05)$ (Table 2$)$.

The most commonly detected tumor subtype was triple negative (ER-, PR-, HER2-) representing $37.7 \%$ of all cases, followed by ER+, PR+, HER2- with $31.2 \%$ of cases, and HER2-enriched (ER-, PR-, HER2+) with $14.5 \%$ of cases. The mean ages across all tumor subtypes were not statistically significantly different $(p=0.558)$. Across all tumor subtypes, the majority of patients had locally advanced tumors and was in the younger age group. However, the relationship between tumor subtypes, tumor stage, and age of patients was not statistically significant $(p=0.097)$ (Table 3$)$.

\section{Age at Diagnosis, Tumor Stage, and Molecular Subtypes of Breast Cancer in SSA}

The results reported in previous studies conducted in SSA countries evaluating the age at diagnosis, tumor stage, and tumor subtypes of breast cancers are aggregated in Table 4. These results showed a high proportion of young patients in SSA (52-86\%) with median ages ranging between 42 and 53 years. Tumor stage III was observed in $38-81 \%$. The overall proportion of triple negative subtype was $31 \%$ ranging from 15 to $53 \%$ with the highest proportions in Western countries compared with East and Southern countries (Fig. 1).

\section{Discussion}

The risk factors associated with $\mathrm{BC}$ disease in Africa and in Rwanda are still unknown. The increasing incidence is thought to be linked to an increase in life expectancy, adoption of western lifestyle including contraceptive use, and possible specific genetic predisposition [34].

Several studies in SSA reported the high prevalence of BC at younger ages with late stage at diagnosis and poor prognosis compared with western countries. Nevertheless, the results on hormone receptor and molecular subtype distribution in African population are still unclear [14].

In the present study, we analyzed the data from 138 confirmed BC cases, evaluating the association between age at diagnosis, tumor stage at presentation, and hormonal receptor profiles or subtypes.

We found that $\mathrm{BC}$ in Rwanda occurs at younger age with a mean age of $49(\mathrm{SD}=13)$ and most patients $(57.2 \%)$ below 50 years of age while $42.8 \%$ of patients were above 50 years. Furthermore, breast cancer was commonly diagnosed between 35 years and 50 years of age with $47.8 \%$ of all cases in this age range. The same observations were made in other SSA countries (Table 4). This finding raises the question of the implication of demographic, genetic, and environmental factors in BC development. The high frequency of young BC patients in Rwanda could be influenced by the demographics in Africa and in Rwanda, where a high number of women are aged less than 50 years in comparison to Europeans [35] (Fig. 2). For example, the Belgian and Rwandan demographic graphs indicate that with similar numbers of total inhabitants, the absolute numbers of women aged 30-49 or 50-69 are similar in Belgium, while in Rwanda, there are 2.4 times more women in the 30-49 than in the 50-69 age range. As there are $52.2 \%$ cancers in the $30-49$ range vs. $37.7 \%$ in the $50-69$ range, more than half of the difference when comparing with
Table 2 The relationship between hormonal receptor statuses, age at diagnosis, and tumor stages

\begin{tabular}{|c|c|c|c|c|c|c|}
\hline HR n $(\%)$ & ER & & PR & & HER2 & \\
\hline $\begin{array}{l}\text { Age } n(\%) \\
\leq 50 \text { years }\end{array}$ & $\begin{array}{l}\text { ER- } \\
42(55.3)\end{array}$ & $\begin{array}{l}\mathrm{ER}+ \\
37(59.7)\end{array}$ & $\begin{array}{l}\mathrm{PR}- \\
47(53.4)\end{array}$ & $\begin{array}{l}\mathrm{PR}+ \\
32(64.0)\end{array}$ & $\begin{array}{l}\text { HER2- } \\
60(55.6)\end{array}$ & $\begin{array}{l}\text { HER2+ } \\
19(63.3)\end{array}$ \\
\hline $\begin{array}{l}n=79 \\
>50 \text { years }\end{array}$ & $34(44.7)$ & $25(40.3)$ & $41(46.6)$ & $18(36.0)$ & $48(44.4)$ & $11(36.7)$ \\
\hline $\begin{array}{l}n=59 \\
p \text { value }\end{array}$ & 0.72 & & 0.30 & & 0.533 & \\
\hline $\begin{array}{l}\text { Locally advanced } \\
n=73\end{array}$ & $52(68.4)$ & $21(33.9)$ & $55(62.5)$ & $18(36.0)$ & $56(51.8)$ & $17(56.7)$ \\
\hline Metastatic & $4(5.3)$ & $6(9.7)$ & $7(7.9)$ & $3(6.0)$ & $6(5.6)$ & $4(1.3)$ \\
\hline $\begin{array}{l}n=10 \\
\text { Missing+ }\end{array}$ & $2(2.6)$ & $6(9.7)$ & $4(4.5)$ & $4(8.0)$ & $8(7.4)$ & $0(0.0)$ \\
\hline$p$ value & $0.00097^{*}$ & & 0.0642 & & 0.483 & \\
\hline
\end{tabular}

*Statistically significative

+Missing data were not considered in the analysis 
Table 3 Tumor subtypes in relation to age at diagnosis and tumor stages

\begin{tabular}{|c|c|c|c|c|c|c|}
\hline Tumor subtype & $\begin{array}{l}\mathrm{ER}+\mathrm{PR}+\mathrm{HER} 2+ \\
\text { (Triple positive) }\end{array}$ & ER + PR + HER2- & $\begin{array}{l}\text { ER - PR - HER2+ } \\
\text { (HER2-enriched) }\end{array}$ & $\begin{array}{l}\text { ER - PR - HER2- } \\
\text { (Triple negative) }\end{array}$ & Others & $p$ value \\
\hline & $7(5.1)$ & $43(31.2)$ & $20(14.5)$ & $52(37.7)$ & $16(11.6)$ & \multirow{3}{*}{$\begin{array}{l}0.558 \\
0.752\end{array}$} \\
\hline Mean \pm SD & $47.3 \pm 9.9$ & $49.9 \pm 11.9$ & $47.3 \pm 10.1$ & $51.9 \pm 14.7$ & $47.3 \pm 12.9$ & \\
\hline $\begin{array}{l}\text { Age } \leq 50 \text { years } \\
n=79\end{array}$ & $4(57.1)$ & $26(60.5)$ & $13(65.0)$ & $26(50.0)$ & $10(62.5)$ & \\
\hline \multicolumn{7}{|l|}{ Age $>50$ years } \\
\hline$n=59$ & $3(42.9)$ & $17(39.5)$ & $7(35.0)$ & $26(50.0)$ & $6(37.5)$ & \\
\hline \multicolumn{7}{|c|}{ Tumor stage: $n(\%)$} \\
\hline $\begin{array}{l}\text { Early stage } \\
n=47\end{array}$ & $2(28.6)$ & $23(53.5)$ & $5(25.0)$ & $12(23.1)$ & $5(31.3)$ & 0.097 \\
\hline \multicolumn{7}{|c|}{ Locally advanced } \\
\hline$n=73$ & $3(42.8)$ & $12(27.9)$ & $13(65.0)$ & $36(69.2)$ & $9(56.2)$ & \\
\hline $\begin{array}{l}\text { Metastatic } \\
n=10\end{array}$ & $2(28.6)$ & $4(9.3)$ & $2(10.0)$ & $2(3.8)$ & 0 & \\
\hline $\begin{array}{l}\text { Missing+ } \\
n=8\end{array}$ & 0 & $4(9.3)$ & 0 & $2(3.8)$ & $2(12.5)$ & \\
\hline
\end{tabular}

* Statistically significant

+Missing data were not considered in analysis

European countries can be explained by the demographic effect. Moreover, it has been estimated that mammography screening programs targeting women between 50 and 69 lead to an over-diagnosis rate of $12-20 \%$, and thus further increase the number of diagnoses in that age range in Europe [36]. Taking together these aspects, it is difficult to conclude that the mean age of BC incidence in significantly lower in SSA than in European countries.

Breast tumor stage is considered as a major determinant of survival from breast cancer where early stage tumor is associated with a better prognosis and a higher survival rate than advanced or tumors $[15,36]$. In our study, tumor stage III was the most common with $62 \%$, while metastatic tumors (stage IV) represented $7.8 \%$ of cases. More than $50 \%$ of patients were clinically node positive at presentation. The high frequency of advanced $\mathrm{BC}$ in our settings is due to a delay in seeking treatment or a system delay in providing care. The reasons for delay in seeking treatment could be the low educational level of patients, a lack of awareness about $\mathrm{BC}$ and associated healthcare, cultural beliefs, and fear of not being considered desirable by marriage partners after mastectomy. In addition, health care services can also be at a long distance from home for the majority of patients. Finally, in many parts of Africa, Rwanda included, patients first consult traditional healers before going to hospitals. System delay can be due to an insufficient medical infrastructure and trained personnel to handle the disease, as well as to the structure of health system in Rwanda. Many Rwandan patients are covered by public insurance, and they have to fist consults a local health center then obtain a transfer to a district hospital before accessing a high-level health care provider at a referral hospital. This complicated channel results in disease progression and delays in proper diagnosis and treatment [8].

The relatively young age of women with $\mathrm{BC}$ and the predominance of advanced tumor stages were reported in several studies in SSA [19, 37-43]. In Western countries the majority of $\mathrm{BC}$ patients present when they are still at a early stage, with a mean age greater than 60 years old, more than 10 years older than in African countries [44, 45].

With regard to hormonal receptor and tumor subtypes profiles, hormonal receptor negative and TN subtype tumors were the most predominant with $55.1 \%$ ER-, $63.8 \%$ PR-, 78.3 HER2-, and 37.7\% TN tumors. No statistically significant association between hormonal receptors, tumor subtypes, and age of patients was observed $(p>0.05)$. However, a statistically significant association was observed between ER status and tumor stage $(p=0.0009)$. The predominance of hormone receptor negative observed in our study participants may be due to the biological characteristics of patients, or to the poor tissue handling. Tissues that are damaged by poor tissue handling are more likely to have incorrect IHC results and may be more likely to be interpreted as TN. Rugwizangoga et al. [46] showed that in our setting only $23.6 \%$ of tissues was processed properly; but the authors did not find any statistical significance between duration of tissue fixation and molecular characteristics of tumors.

Nevertheless, our findings were consistent with other findings reported in African American (AA) and European women with African Descent $[47,48]$. Studies in African American women reported that the prevalence of TNBC and was $2-3$ fold higher compared with White women, ranging from 29.8 
Table 4 Comparison of distribution of aggressive molecular subtypes, younger age at diagnosis, and advanced tumor stage of breast cancer from selected Sub-Saharan African studies

\begin{tabular}{|c|c|c|c|c|c|c|c|c|c|}
\hline \multirow[t]{2}{*}{ Authors (year) } & \multirow[t]{2}{*}{ Location } & \multirow{2}{*}{$\begin{array}{l}\text { Sample } \\
\text { size }\end{array}$} & \multirow{2}{*}{$\begin{array}{l}\text { Age at } \\
\text { diagnostic } \\
(\text { mean } \pm \mathrm{SD}) / \\
\text { Median } \\
\text { (Range) }\end{array}$} & \multirow{2}{*}{$\begin{array}{l}\text { Age } \leq 50 \\
n(\%)\end{array}$} & \multicolumn{2}{|c|}{ Advanced tumors } & \multirow{2}{*}{$\begin{array}{l}n(\%) g_{\text {专 } n} \\
(\%) \\
\text { Triple } \\
\text { negative }\end{array}$} & \multirow{2}{*}{$\begin{array}{l}\text { HER2- } \\
\text { enriched } \\
n(\%)\end{array}$} & \multirow[t]{2}{*}{ Reference } \\
\hline & & & & & $\begin{array}{l}n(\%) \\
\text { Stage III }\end{array}$ & $\begin{array}{l}\text { Metastatic } \\
n(\%) \\
\text { (Stage IV) }\end{array}$ & & & \\
\hline & $\begin{array}{l}\text { Eastern/Middle } \\
\text { Africa }\end{array}$ & & & & & & & & \\
\hline Our study & Rwanda & 138 & $49.7 \pm 12.9$ & $79(57.2)$ & $73 / 128(57.03)$ & $10 / 128(7.8)$ & $52(37.7)$ & $20(14.5)$ & \\
\hline $\begin{array}{l}\text { Sayed et al. } \\
\quad(2014)\end{array}$ & Kenya, Nairobi & 301 & $48.2 \pm 10.9$ & $164(54.0)$ & 43/99 (43.4) & $18 / 99(18.2)$ & $60(20.2)$ & $22(7.7)$ & {$[18]$} \\
\hline $\begin{array}{l}\text { Rambau et al. } \\
\text { (2014) }\end{array}$ & $\begin{array}{l}\text { Tanzania, } \\
\text { North-West }\end{array}$ & 52 & $46(25-82)$ & $27(51.9)$ & $40(76.9)$ & NA & $19(38.4)$ & $5(9.6)$ & {$[19]$} \\
\hline $\begin{array}{l}\text { Galukande et al. } \\
\text { (2014) }\end{array}$ & Uganda, Mulago & 226 & $50 \pm 13$ & $152(67.3)$ & $110 / 169(65.1)$ & $31 / 169(18.3)$ & $76(34.07)$ & $49(22.0)$ & $\begin{array}{l}\text { aaa } \\
{[20]}\end{array}$ \\
\hline $\begin{array}{l}\text { Luyeye et al. } \\
\text { (2015) }\end{array}$ & $\begin{array}{c}\text { Democratic } \\
\text { Republic } \\
\text { of Congo, } \\
\text { Kinshasa }\end{array}$ & 87 & 47.5 (19-94) & $49(56.3)$ & $65(74.7)$ & NA & 13 (14.99) & $7(8.05)$ & {$[21]$} \\
\hline $\begin{array}{l}\text { Hadgu et al. } \\
\text { (2018) }\end{array}$ & $\begin{array}{l}\text { Ethiopia, Addis } \\
\text { Ababa }\end{array}$ & 112 & $43 \pm 14$ & $70(62.5)$ & $36(37.0)$ & $4(4.0)$ & $25(23)$ & $11(10.0)$ & {$[22]$} \\
\hline $\begin{array}{l}\text { Eber-Schulz et al. } \\
\text { (2018) }\end{array}$ & $\begin{array}{l}\text { Ethiopia, } \\
\text { Western }\end{array}$ & 107 & $43 \pm 14.3$ & $80(74.8)$ & $59(57.3)$ & $7(6.5)$ & $26(24.8)$ & $23(20.9)$ & {$[23]$} \\
\hline $\begin{array}{l}\text { Jiagge et al. } \\
\text { (2016) }\end{array}$ & $\begin{array}{l}\text { Ethiopia, Addis } \\
\text { Ababa }\end{array}$ & 93 & $43(23-76)$ & NA & $44(53.6)$ & NA & $13(15)$ & $12(12.6)$ & {$[24]$} \\
\hline $\begin{array}{l}\text { Sengal et al. } \\
\text { (2017) }\end{array}$ & $\begin{array}{l}\text { Erythrea and } \\
\quad \text { Sudan } \\
\text { Western Africa }\end{array}$ & 678 & $55.5 \pm 14.3$ & $452(66.7)$ & $294(43.5)$ & NA & $232(34.3)$ & $85(16.0)$ & {$[25]$} \\
\hline $\begin{array}{l}\text { Traoré et al. } \\
\text { (2019) }\end{array}$ & Guinea & 58 & $45 \pm 14$ & $32(55.2)$ & $28(48.3)$ & $11(19.0)$ & $15(25.9)$ & $13(22.4)$ & {$[26]$} \\
\hline $\begin{array}{l}\text { Ly et al. } \\
\text { (2012) }\end{array}$ & Mali, Bamako & 114 & $48.8 \pm 0.53$ & $74(68.0)$ & $91(80.0)$ & $49(43.0)$ & $52(46.0)$ & $5(4.0)$ & {$[27]$} \\
\hline $\begin{array}{l}\text { Jiagge et al. } \\
\text { (2016) }\end{array}$ & Ghana, Kumasi & 234 & 49 (24-92) & NA & $84(53.8)$ & NA & $124(53.2)$ & 27 (11.6) & {$[24]$} \\
\hline $\begin{array}{l}\text { Usman et al. } \\
\text { (2019) }\end{array}$ & Nigeria & 478 & $46.3(24-85)$ & $271(56.7)$ & 169 (37.6) & NA & $\begin{array}{l}55 / 118 \\
(46.7)\end{array}$ & $\begin{array}{l}21 / 118 \\
(17.9)\end{array}$ & {$[28]$} \\
\hline $\begin{array}{l}\text { Ukah et al. } \\
\text { (2017) }\end{array}$ & Nigeria, South & 123 & $46.9 \pm 13$ & 75 61.06) & $66(53.7)$ & NA & $50(40.7)$ & $13(10.6)$ & [29] \\
\hline $\begin{array}{l}\text { Titloye et al. } \\
\text { (2016) }\end{array}$ & Nigeria & 835 & $48.6 \pm 12.4$ & $712(85.5)$ & $388(46.5)$ & NA & $396(47.7)$ & $164(19.6)$ & {$[30]$} \\
\hline $\begin{array}{l}\text { Huo et al. } \\
\text { (2009) }\end{array}$ & $\begin{array}{l}\text { Nigeria and } \\
\text { Senegal } \\
\text { Southern Africa }\end{array}$ & 378 & $44.8 \pm 11.8$ & $251(66.0)$ & $168(44.4)$ & NA & $102(27.2)$ & $57(15.1)$ & {$[31]$} \\
\hline $\begin{array}{l}\text { McCormack } \\
\text { et al. (2013) }\end{array}$ & $\begin{array}{l}\text { South Africa, } \\
\text { Soweto }\end{array}$ & 1216 & $48.1 \pm 13.1$ & $472(38.8)$ & $533(43.8)$ & 107 (8.9) & $246(20.4)$ & $117(11.04)$ & {$[32]$} \\
\hline $\begin{array}{l}\text { Miguel et al. } \\
\quad(2017)\end{array}$ & Angola, Luanda & 140 & $47(24-84)$ & NA & $91(65.0)$ & $5(3.6)$ & $44(31.4)$ & $22(15.7)$ & {$[33]$} \\
\hline
\end{tabular}

[24] to 46.6\% [49]. For example, Carey et al. [50] in Carolina Breast Cancer Study found the predominance of TN tumor in AA women in comparison to White American women $(39 \%$ vs16\%). Clarke et al. [51] and Lund et sal. [49] reported a higher rate of TN cases in black women compared with white women in each age group [51]. Keenan et al. [52] made similar conclusions after analyzing TN cases from The Cancer Genome Atlas (TCGA) and showed that TN and basal tumors were more prevalent in AA in comparison to white women (33.3\% vs. $14.19 \% \mathrm{TN}$ and $34.8 \%$ vs. 16.1 basal). In UK, Bowen et al. amazed data from UK-based BC cohort and found that $22 \%$ of black women had TN tumors in comparison to $15 \%$ of white women [53].

Inversely, in Western countries, BC is shown to be hormone receptor positive in $70-80 \%$ and only $10-20 \%$ of tumors are found to be TN [54-56]. 


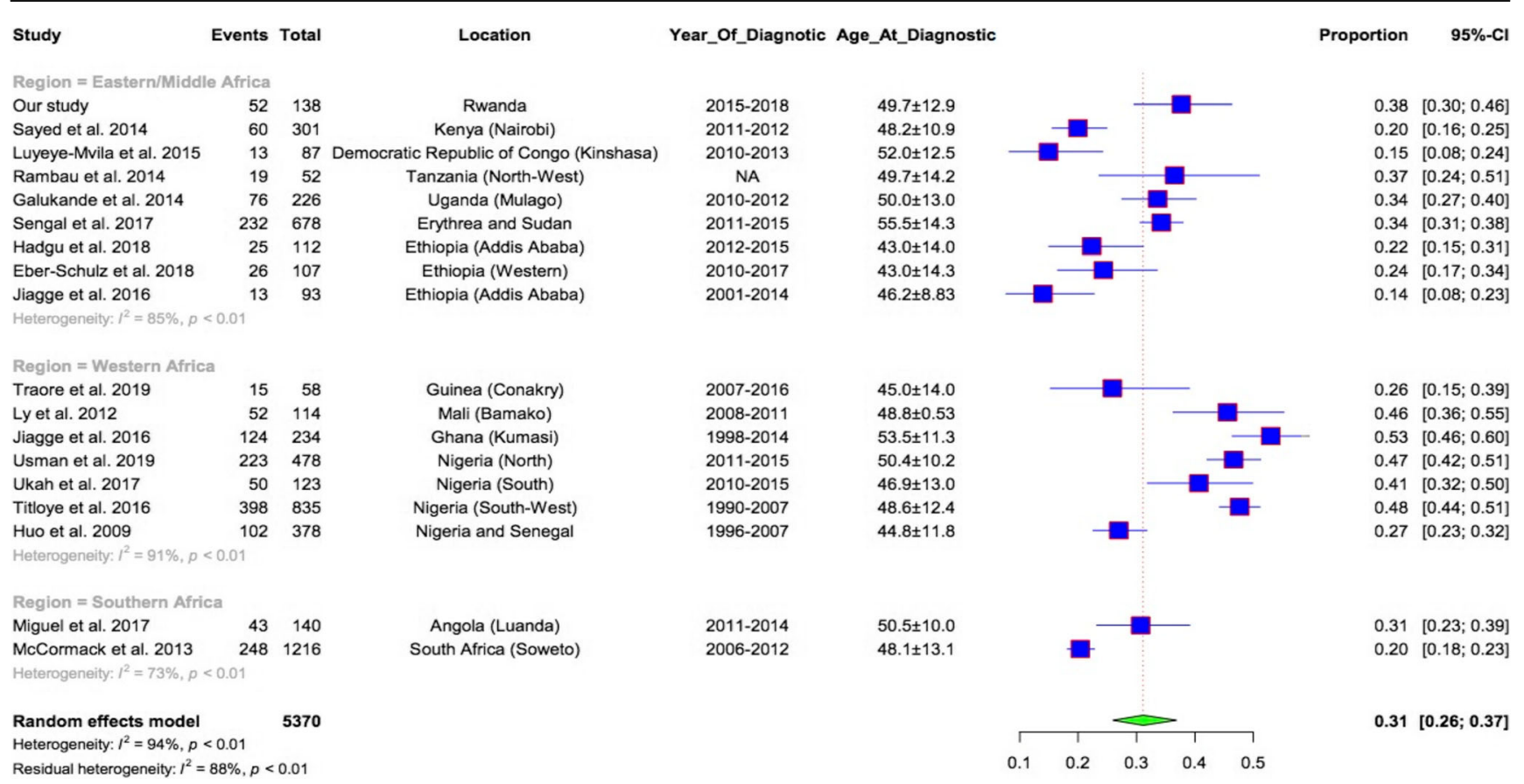

Fig. 1 Comparison of proportions of triple negative breast tumors reported in SSA studies

To compare our results, we have reviewed the studies conducted in SSA countries evaluating the age at diagnosis, stage at presentation, and tumor subtypes (Table 4).

Studies conducted in Eastern African countries such as Uganda [20], Tanzania [19], Erythrea, and Sudan [25], and Ethiopia $[22,24]$ reported a predominance of hormone receptor negative with proportions of TNBC slightly higher than in the South of Africa. In this region where Rwanda is located, the proportions of $\mathrm{TN}$ were compared with our results and vary from 30 to $39 \%$. Nevertheless, other studies from Kenya [18] and Democratic Republic of Congo [21] reported the predominance of hormone receptor positive with a low proportion of TN tumors ( $20 \%$ and $15 \%$, respectively).

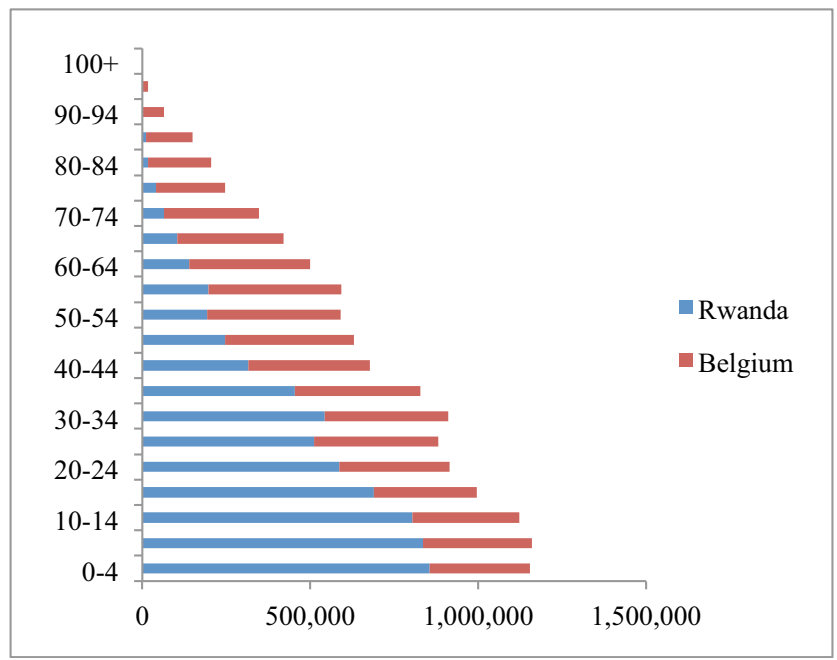

Fig. 2 Comparison of distribution of female population between Rwanda and Belgium in relation to age
In the Western region of Africa, the highest proportions of hormones receptor negatives and TNBC tumors were reported. A study conducted in six geographic areas of Nigeria and Senegal showed that ER- negative tumors were the most predominant comprising $76 \%$ of cases. In Mali, Ly et al. found a high frequency of TN tumors with $46 \%$ [27]. In Nigeria, the frequency of TN tumors was 40-48\% [54-56]. In Kumasi, Ghana, the same high proportions of TN (53.2\% and 53.8\%) were reported [22, 24]. However, studies conducted in Southern African countries like South Africa, Namibia, and Angola [18, 22, 25] found that the majority of tumors were ER positive. TN tumors represented $20-32 \%$ with a high frequency in black women as compared with white patients. Figure 1 shows that the overall proportion of triple negative in Africa was $31 \%(95 \% \mathrm{CI}=26-37 \%)$, which is superior to the proportions of TNBC reported in Western countries (10-20\%). The distribution of hormone receptor negative and TN subtype increases from South to North and from East/Middle to Western Africa with a slight variability within each region. This may be partly confirmed by the study conducted by Jiagge et al., where ER negative and TNBC in Ghana (West Africa) were higher with $71.1 \%$ and $53.8 \%$, respectively, than in Ethiopia (East Africa) with 28.6 ER negative and $15 \%$ of TNBC [24]. In our study, the proportions of TNBC $(37.7 \%)$ observed from Rwanda (Middle Africa) was higher than observations made in Ethiopia, but less than the TN cases observed in Ghana, suggesting that Middle Africa may be an intermediate between East and Western Africa. The differences of tumor subtypes in SSA could be linked to environmental or genetic factors related to geographical location but will have to be confirmed in large Pan-African studies with a unique methodology. 
A study conducted by Sung et al. confirmed the variability of prevalence of TN breast tumors in black women according to geographical origin. Sung et al. evaluated breast cancer subtypes among Black American women in the USA from different birthplaces and found that the proportion of TNBC was higher in US born followed by Western-Africa born followed by Caribbean-born and then Eastern-African black born women [57]. Our findings add more evidence to the suggestions made by Sung et al. that it is important to consider geographical origin in studies characterizing $\mathrm{BC}$ in women with African descent.

This is the first study that provides data on hormone profiles and tumor subtypes of BC in Rwanda compared with age at diagnosis and tumor stages. One of the limitations of our study was the lack of available data on hormonal receptor status, age at diagnosis, and/or stage at presentation. Therefore, a high number of patients were excluded from the analysis because of missing data on these key variables considered in our study. In addition, information about patients' treatment and mortality was often missing. This would have allowed us to calculate the responses to treatment and survival rate after diagnosis according to tumor subtypes. Nevertheless, our results provide important information about tumor characteristics of BC in Rwanda and in Africa. Future large studies investigating $\mathrm{BC}$ in SSA are required.

\section{Conclusion}

The present study showed that in Rwanda, BC is characterized by the predominance of hormone negative and triple negative tumor subtypes, with a young age at diagnosis and a high frequency of advanced tumors. However, no statistically significant association of tumor subtypes, age, and tumor stage was observed. Larger prospective studies of BC series are necessary to confirm the present results and to provide an accurate portrait of the disease presentation and progression in various African regions for a better disease management.

Indeed, our findings and results from other SSA studies suggest that there is a geographic variability in the distribution of hormonal receptor and tumor subtypes. Further confirmatory studies could examine genetics and environmental factors that may play a role in the differences of tumor characteristics in SSA populations.

Acknowledgments We extend our appreciation to the staff of outpatient department, pathology, gynecology, and surgery services of CHUB, CHUK, and RMH for their contribution during data collection.

Author's Contribution All authors contributed to the study conception and design. Material and methods, data collection, and analysis were performed by Jeanne P. Uyisenga, Yvan Butera, Ahmed Debit, Claire Josse, Costa C. Ainhoa, Emile Kalinganire, Aimée P. Cyuzuzo Nicole, Umurungi, Yves Kalinijabo, and Simeon Uwimana. The first draft of the manuscript was written by Jeanne P. UYISENGA, and all authors commented on previous versions of the manuscript. All authors read and approved the final manuscript. Claire Josse, Leon Mutesa, and Vincent Bours supervised the whole work.

Funding Information This study was supported by the project R1 of the Cooperation program between the University of Rwanda (UR), Rwanda, and Académie de Recherche et d'Enseignement Supérieure (ARES), Belgium (UR-ARES R1).

Data Availability The datasets used generated during and /or analyzed during the current study are available from the corresponding author on reasonable request.

\section{Compliance with Ethical Standards}

Conflict of Interest The authors declare that they have no conflict of interest.

Ethical Approval All procedures performed in this study were in accordance of the ethical standards of the Institutional Review Board of the College of Medicine and Health Sciences at University of Rwanda (No. 209/CMHS IRB/2017) and with the 1964 Helsinki declaration of and its later amendments or comparable ethical standards.

Consent to Participate This research was a retrospective descriptive study, which used patient electronic medical record files to get clinical information. The approval was obtained from the central Institutional Review Board of College of Medicine and Health Sciences of the University of Rwanda, which ensured that the data were handled anonymously and in a strict confidential way.

\section{References}

1. WHO (2018) Latest global cancer data: cancer burden rises to 18.1 million new cases and 9.6 million cancer deaths in 2018 Latest global cancer data: cancer burden rises to 18.1 million new cases and 9.6 million cancer deaths in 2018. Press release no 2

2. Ferlay J, Soerjomataram I, Dikshit R et al (2012) Cancer incidence and mortality worldwide: sources, methods and major patterns in GLOBOCAN. 2012. https://doi.org/10.1002/ijc.29210

3. Sighoko D, Kamaté B, Traore C, Mallé B, Coulibaly B, Karidiatou A, Diallo C, Bah E, McCormack V, Muwonge R, Bourgeois D, Gormally E, Curado MP, Bayo S, Hainaut P (2013) Breast cancer in pre-menopausal women in West Africa: analysis of temporal trends and evaluation of risk factors associated with reproductive life. Breast 22:828-835. https://doi.org/10.1016/j.breast.2013.02.011

4. Sankaranarayanan R, Swaminathan R, Brenner H, Chen K, Chia KS, Chen JG, Law SCK, Ahn YO, Xiang YB, Yeole BB, Shin HR, Shanta V, Woo ZH, Martin N, Sumitsawan Y, Sriplung H, Barboza AO, Eser S, Nene BM, Suwanrungruang K, Jayalekshmi P, Dikshit $\mathrm{R}$, Wabinga $\mathrm{H}$, Esteban DB, Laudico A, Bhurgri Y, Bah E, alHamdan N (2010) Cancer survival in Africa, Asia, and Central America: a population-based study. Lancet Oncol 11:165-173. https://doi.org/10.1016/S1470-2045(09)70335-3

5. Shulman LN, Mpunga T, Tapela N, Wagner CM (2014) Bringing cancer care to the poor: experiences from Rwanda. Nat Publ Gr 14: 815-821. https://doi.org/10.1038/nrc3848

6. Pace EL, Dusengimana JMV, Hategekimana V, Hamissy Habineza JBB et al (2016) Benign and malignant breast disease at Rwanda's First Public Cancer Referral Center. Oncologist 21:571-575 
7. Dietze EC, Sistrunk C, Miranda-carboni G et al (2015) Triplenegative breast cancer in African-American women: disparities versus biology. Nat Rev Cancer 15(4):248-254. https://doi.org/10. 1038/nrc3896

8. Pace LE, Mpunga T, Hategekimana V, Dusengimana JMV, Habineza $\mathrm{H}$, Bigirimana JB, Mutumbira C, Mpanumusingo E, Ngiruwera JP, Tapela N, Amoroso C, Shulman LN, Keating NL (2015) Delays in breast cancer presentation and diagnosis at two rural cancer referral centers in Rwanda. Oncologist 20:780-788. https://doi.org/10.1634/theoncologist.2014-0493

9. Malhotra GK, Zhao X, Band H, Band V (2010) Histological, molecular and functional subtypes of breast cancers. https://doi.org/10. $4161 / \mathrm{cbt} .10 .10 .13879$

10. Sinn HP, Kreipe H (2013) A brief overview of the WHO classification of breast tumors, 4th edition, focusing on issues and updates from the 3rd edition. Breast Care 8:149-154

11. Mori I, Yang Q, Kakudo K (2002) Predictive and prognostic markers for invasive breast cancer. Pathol Int 52:186-194

12. Higgins MJ, Baselga J, Higgins MJ, Baselga J (2011) Targeted therapies for breast cancer find the latest version: review series targeted therapies for breast cancer. J Clin Investig 121:37973803. https://doi.org/10.1172/JCI57152

13. Yersal O, Barutca S (2014) Biological subtypes of breast cancer: prognostic and therapeutic implications. World J Clin Oncol 5:412424

14. Brinton LA, Figueroa JD, Awuah B, Yarney J, Wiafe S, Wood SN, Ansong D, Nyarko K, Wiafe-Addai B, Clegg-Lamptey JN (2014) Breast cancer in Sub-Saharan Africa: opportunities for prevention. Breast Cancer Res Treat 144:467-478. https://doi.org/10.1007/ s10549-014-2868-z.Breast

15. Allred DC, Harvey JM, Berardo MCG (1998) Prognostic and predictive factors in breast cancer by immunohistochemical analysis. Mod Pathol 11:155-168. https://doi.org/10.1053/ctrv.2000.0207

16. Elston CW, Ellis IO (2002) Pathological prognostic factors in breast cancer. I. The value of histological grade in breast cancer: experience from a large study with long-term follow-up. C. W. Elston \& I. O. Ellis. Histopathology 1991; 19; 403-410. Author commentary. Histopathology 41:151-151. https://doi.org/10.1046/j.1365-2559. 2002.14691.x

17. Edge SB, Compton CC (2010) The american joint committee on cancer: the 7th edition of the AJCC cancer staging manual and the future of TNM. Ann Surg Oncol 17:1471-1474. https://doi.org/10. 1245/s10434-010-0985-4

18. Sayed S, Moloo Z, Wasike R, Bird P, Oigara R, Govender D, Kibera J, Carrara H, Saleh M (2014) Is breast cancer from Sub Saharan Africa truly receptor poor? Prevalence of ER / PR / HER2 in breast cancer from Kenya. Breast 23:591-596. https:// doi.org/10.1016/j.breast.2014.06.006

19. Rambau P, Masalu N, Jackson K, Chalya P, Serra P, Bravaccini S (2014). Triple negative breast cancer in a poor resource setting in North-Western Tanzania : a preliminary study of 52 patients. BMC Res Notes 7:399. http://www.biomedcentral.com/1756-0500/7/399

20. Galukande M, Wabinga H, Mirembe F et al (2014) Molecular breast cancer subtypes prevalence in an indigenous Sub Saharan African population. Pan Afr Med J 17:249. https://doi.org/10. 11604/pamj.2014.17.249.330

21. Luyeye Mvila G, Batalansi D, Praet M, Marchal G, Laenen A, Christiaens MR, Brouckaert O, Ali-Risasi C, Neven P, van Ongeval C (2015) Prognostic features of breast cancer differ between women in the Democratic Republic of Congo and Belgium. Breast 24:642-648. https://doi.org/10.1016/j.breast.2015.07.031

22. Hadgu E, Seifu D, Tigneh W, Bokretsion Y, Bekele A, Abebe M, Sollie T, Merajver SD, Karlsson C, Karlsson MG (2018) Breast cancer in Ethiopia: evidence for geographic difference in the distribution of molecular subtypes in Africa. BMC Womens Health 18: 40. https://doi.org/10.1186/s12905-018-0531-2
23. Eber-Schulz P, Tariku W, Reibold C, Addissie A, Wickenhauser C, Fathke C, Hauptmann S, Jemal A, Thomssen C, Kantelhardt EJ (2018) Survival of breast cancer patients in rural Ethiopia. Breast Cancer Res Treat 170:111-118. https://doi.org/10.1007/s10549$018-4724-z$

24. Jiagge E, Jibril AS, Chitale D et al (2016) Comparative analysis of breast cancer phenotypes in African American, White American, and West Versus East African patients: correlation between African ancestry and triple-negative breast cancer. https://doi.org/10.1245/ s10434-016-5420-z

25. Sengal AT, Haj-mukhtar NS, Elhaj AM et al (2017) Immunohistochemistry defined subtypes of breast cancer in 678 Sudanese and Eritrean women: hospitals based case series. MBC Cancer 17:804. https://doi.org/10.1186/s12885-017-3805-4

26. Traoré B, Koulibaly M, Diallo A, Bah M (2019) Molecular profile of breast cancers in Guinean oncological settings. Pan Afr Med J 33. https://doi.org/10.11604/pamj.2019.33.22.18189

27. Ly M, Karim A, Levy P et al (2012) Reducing the worldwide burden of cancer high incidence of triple-negative tumors in subSaharan Africa: a prospective study of breast cancer characteristics and risk factors in Malian women seen in a Bamako University Hospital. https://oi.org/10.1159/000341541

28. Usman A, Iliyasu Y, Atanda A (2019) Molecular subtyping of carcinoma of the female breast in a tertiary teaching hospital in Northern Nigeria. Ann Trop Pathol 10:20. https://doi.org/10.4103/ atp.atp_51_18

29. Ukah CO (2017) The Immunohistochemical profile of breast cancer in indigenous women of Southeast Nigeria. Ann Med Health Sci Res 7:83-87

30. Titloye NA, Foster A, Omoniyi-Esan GO, Komolafe AO, Daramola AO, Adeoye OA, Adisa AO, Manoharan A, Pathak D, D"Cruz MN, Alizadeh Y, Lewis PD, Shaaban AM (2016) Histological features and tissue microarray taxonomy of Nigerian breast cancer reveal predominance of the high-grade triple-negative phenotype. Pathobiology 83:24-32. https://doi.org/10.1159/ 000441949

31. Huo D, Ikpatt F, Khramtsov A, Dangou JM, Nanda R, Dignam J, Zhang B, Grushko T, Zhang C, Oluwasola O, Malaka D, Malami S, Odetunde A, Adeoye AO, Iyare F, Falusi A, Perou CM, Olopade OI (2009) Population differences in breast cancer: survey in indigenous african women reveals over-representation of triple-negative breast cancer. J Clin Oncol 27:4515-4521. https://doi.org/10.1200/ JCO.2008.19.6873

32. McCormack VA, Joffe M, van den Berg E et al (2013) Breast cancer receptor status and stage at diagnosis in over 1,200 consecutive public hospital patients in Soweto, South Africa: A case series. Breast Cancer Res 15:R84. https://doi.org/10.1186/bcr3478

33. Miguel F, Lopes LV, Ferreira E et al (2017) Breast cancer in Angola, molecular subtypes: a first glance. Ecancermedicalscience 11. https://doi.org/10.3332/ecancer.2017. 763

34. Akarolo-anthony SN, Ogundiran TO, Adebamowo CA (2020) Emerging breast cancer epidemic: evidence from Africa. Breast Cancer Res 12(Suppl 14):S8

35. http://Statbel.fgov.be/en/themes/populations/structure-population http://worldpopulationreview.com/countries/rwanda-population/ Accessed 10 November 2019

36. Katalinic A, Eisemann N, Kraywinkel $\mathrm{K}$ et alBreast cancer incidence and mortality before and after implementation of the German mammography screening program Short title: Effects of the German mammography screening program. https://doi.org/10. 1002/ijc. 32767

37. Elston CW, Ellis IO (1991) Pathological prognostic factors in breast cancer. I. The value of histological grade in breast cancer: experience from a large study with long-term follow-up. Histopathology 19:403-410. https://doi.org/10.1111/j.1365-2559.1991.tb00229.x 
38. Effi AB, Aman NA, Koui BS, Koffi KD, Traoré ZC, Kouyate M (2017) Immunohistochemical determination of estrogen and progesterone receptors in breast cancer: relationship with clinicopathologic factors in 302 patients in Ivory Coast. BMC Cancer 17:105. https://doi.org/10.1186/s12885-017-3105-z

39. Sawe RT, Kerper M, Badve S, Li J, Sandoval-Cooper M, Xie J, Shi Z, Patel K, Chumba D, Ofulla A, Prosperi J, Taylor K, Stack MS, Mining S, Littlepage LE (2016) Aggressive breast cancer in western Kenya has early onset, high proliferation, and immune cell infiltration. BMC Cancer 16:204. https://doi.org/10.1186/s12885-0162204-6

40. Balekouzou A, Yin P, Bekolo CE, Pamatika CM, Djeintote M, Nambei SW, Ba-Mpoutou B, Mandjiza DR, Shu C, Yin M, Qing T, Koffi B (2018) Histo-epidemiological profile of breast cancers among women in the Central African Republic: about 174 cases. BMC Cancer 18:387. https://doi.org/10.1186/s12885-018-4256-2

41. Mody GN, Nduaguba A et al (2013) Characteristics and presentation of patients with breast cancer in Rwanda. Am J Surg 205:409413. https://doi.org/10.1016/j.amjsurg.2013.01.002

42. Ntekim A, Nufu FT, Campbell OB (2009). Breast cancer in young women in Ibadan, Nigeria. African Health Sciences 9(4):242-246

43. Boder JME, Abdalla FBE, Elfageih MA et al (2011) Breast cancer patients in Libya: comparison with European and central African patients. Oncol Lett 2:323-330. https://doi.org/10.3892/ol.2011. 245

44. Renard F, Van Eycken L, Arbyn M (2011) High burden of breast cancer in Belgium: recent trends in incidence (1999-2006) and historical trends in mortality (1954-2006). Arch Public Heal 69: 1-11. https://doi.org/10.1186/0778-7367-69-2

45. American cancer Society (2018) Breast cancer. Facts \& Figures 2017-2018. Am Cancer Soc 2020:2019-2020

46. Ndayisaba M-C, Rugwizangoga B, de Dieu Baryabagaya J et al (2015) Effects of fixation duration on hormone receptor status of primary breast cancers in a tertiary hospital of Rwanda. Imp J Interdiscip Res 2(11):756-762

47. Sturtz LA, Meller J, Mmamula K, Shriver CD, Ellsworth ER (2014) Outcome disparities in African American women with triple negative breast cancer: a comparison of epidemiological and molecular factors between African American and Caucasian women with triple negative breast cancer. BMC Cancer 14
48. Stead LA, Lash TL, Sobieraj JE et al (2009) Triple-negative breast cancers are increased in black women regardless of age or body mass index. https://doi.org/10.1186/bcr2242

49. Lund MJ, Trivers KF, Porter PL, Coates RJ, Leyland-Jones B, Brawley OW, Flagg EW, O’Regan RM, Gabram SGA, Eley JW (2009) Race and triple negative threats to breast cancer survival: a population-based study in Atlanta, GA. Breast Cancer Res Treat 113:357-370. https://doi.org/10.1007/s10549-008-9926-3

50. Carey LA, Perou CM, Livasy CA, et al (2006) Race, breast cancer subtypes, and survival in the Carolina Breast Cancer Study. 295

51. Clarke CA, Keegan THM, Yang J, Press DJ, Kurian AW, Patel AH, Lacey JV Jr (2012) Age-specific incidence of breast cancer subtypes: understanding the black-white crossover. J Natl Cancer Inst 104:1094-1101. https://doi.org/10.1093/jnci/djs264

52. Keenan T, Moy B, Mroz EA, Ross K, Niemierko A, Rocco JW, Isakoff S, Ellisen LW, Bardia A (2015) Comparison of the genomic landscape between primary breast cancer in African American versus white women and the association of racial differences with tumor recurrence. J Clin Oncol 33:3621-3627. https://doi.org/10. 1200/JCO.2015.62.2126

53. Bowen RL, Duffy SW, Ryan DA, Hart IR, Jones JL (2008) Early onset of breast cancer in a group of British black women. Br J Cancer 98:277-281. https://doi.org/10.1038/sj.bjc.6604174

54. Parise CA, Bauer KR, Brown MM, Caggiano V (2009) Breast cancer subtypes as defined by the estrogen. https://doi.org/10. 1111/j.1524-4741.2009.00822.x

55. Foulkes WD, Smith IE, Reis-Filho JS (2010) Triple negative breast cancer. N Engl J Med 363:1938-1948. https://doi.org/10.1056/ NEJMra1001389

56. Boyle P (2012) Triple-negative breast cancer: epidemiological considerations and recommendations. Ann Oncol 23:8-13. https://doi. org/10.1093/annonc/mds187

57. Sung H, DeSantis CE, Fedewa SA et al (2019) Breast cancer subtypes among Eastern-African-born black women and other black women in the United States. Cancer 125:3401-3411. https://doi. org/10.1002/cncr.32293

Publisher's Note Springer Nature remains neutral with regard to jurisdictional claims in published maps and institutional affiliations. 